\title{
P02.160. The psychosomatic model for clinical oncology
}

\author{
A Zhirkov, E Stepanchuk \\ From International Research Congress on Integrative Medicine and Health 2012 \\ Portland, Oregon, USA. 15-18 May 2012
}

\section{Purpose}

The studies suggested a psychodiagnosis of cancer patients according to the $\mathrm{SPb}$ regenerative pyramid model.

\section{Methods}

Thirty patients with lymphoma diseases, 30 patients with cancer of the reproductive organs (breast cancer and cervical cancer), and 39 patients with chronic myelogenous and lymphocytic leukemia were investigated.

\section{Results}

The peculiarities of response to diseases in cancer patients were found according to the nosological group. It was shown that, despite the dominance of conventional adaptive ergopathic type of attitude to the disease (which is characterized by an obsessive attitude to work) in all studied groups, the presence of a high level of sensitivity component illustrates the lack of success to adapt to the situation of the disease. However, the presence of strong positive correlation between the type of response to disease and the level of depression in a group of hematological malignancies suggests a maladaptive system attitude to the disease in these patients. An analysis of coping behavior (by the method of Ways of Coping Checklist) of these categories of patients revealed a negative correlation between the level of depression and the most stressful coping strategies: seeking social support and positive reappraisal.

\section{Conclusion}

The obtained results have theoretical value in understanding the regularities of formation of coping behavior of patients with cancer pathology in different nosological groups.

Saint Petersburg State University, Saint Petersburg, Russian Federation
Published: 12 June 2012

doi:10.1186/1472-6882-12-S1-P216

Cite this article as: Zhirkov and Stepanchuk: P02.160. The psychosomatic model for clinical oncology. BMC Complementary and Alternative Medicine 2012 12(Suppl 1):P216.
Submit your next manuscript to BioMed Central and take full advantage of:

- Convenient online submission

- Thorough peer review

- No space constraints or color figure charges

- Immediate publication on acceptance

- Inclusion in PubMed, CAS, Scopus and Google Scholar

- Research which is freely available for redistribution

Submit your manuscript at www.biomedcentral.com/submit
() Biomed Central

\section{() Biomed Central}

